\title{
DIGITAL CONTENT PORTABILITY AND ITS RELATION TO CONFORMITY WITH THE CONTRACT ${ }^{*}$
}

by

PAVEL KOUKAL ${ }^{* *}$

In this paper, the author analyses the possible convergences and divergences of two pieces of EU legislation: The Portability Regulation and the Digital Content Directive. Both EU laws address the issue of access to digital content from different perspectives and complement each other. However, they use different legal terminology and, in some respects, have a different scope of application (mainly about the requirement of monetary counter-performance). The Portability Regulation focuses on the cross-border portability of digital content [Art. 3 (1) Portability Regulation), while the Digital Content Directive specifies the consumer rights related to the distribution of digital content and subsumes the accessibility of digital content under the concept of "conformity of the digital content with the contract" [Art. 6 (1), (2) Digital Content Directive]. The author explains that the consumer who is not allowed to use the digital content in the EU Member States besides the Member State of his or her residence should be entitled to assert legal claims arising from the non-conformity of the digital content with the contract.

\section{KEY WORDS}

Digital Content, Portability, Accessibility, Conformity with the Contract, Consumer Remedies, CESL, Serious Breach of the Contract

\footnotetext{
The author would like to express his gratitude to prof. Marketa Trimble from the William S. Boyd School of Law, UNLV (USA) for the substantive comments on the working versions of this paper. Some minor parts of this paper were presented at the ALAI 2019 Congress and published in Koukal, P (2018), p. 814-820. The original paper discusses the relationship of the Portability Regulation to the draft of the Digital Content Directive, not to the text of the directive itself, as it was not yet issued at the time of the first paper publication.

** pavel.koukal@law.muni.cz, associate professor, Masaryk University, Brno, Czech Republic.
} 


\section{INTRODUCTION}

Cross-border issues related to the use of the digital content by consumers have been covered by several pieces of EU legislation in recent years (see Fn 5-11). The availability of digital goods or services in the on-line environment is of a complex nature and can be viewed from different perspectives, each of which concerns various stages of making digital assets available to the consumer audience ${ }^{1}$.

Existing differences in the laws of the EU Member States regarding national consumer protection and contract law are seen as the principal barrier which prevents consumers from enjoying the full benefits of cross-border e-commerce with digital assets. Also, business operators who must adapt their services to different legal conditions set by the national legislations ${ }^{2} \mathrm{i} n$ the field of contracts, consumer or copyright protection ${ }^{3}$ see the current state as a significant barrier to their activities.

When legal regulation of the digital assets dissemination is concerned, we can see several phases where EU law interferes with the process of making digital content available to users (consumers). At the beginning of the digital assets regulatory chain, we find various legal regulations whose subject is intellectual property ${ }^{4}$ and personal data protection ${ }^{5}$. In the middle of the distribution chain, we find the legal regulation of the (i) intermediaries liability; ${ }^{6}$ (ii) collecting societies management; ${ }^{7}$ (iii) rights to access the digital content of libraries, universities, and research

1 Trimble, M (2012), p. 624 ff.; Hoffman, J (2016), p. 148 ff.; Helberger, N et al. (2013), p. 42-45; Staudenmayer, D (2016), p. 2721, 2722; Spindler, G (2016) Digitale Wirtschaft - analoges Recht: Braucht das BGB ein Update?, p. 805 ff.; Spindler, G (2016) Verträge über digitale Inhalte - Anwendungsbereich und Ansätze Vorschlag der EU-Kommission zu einer Richtlinie über Verträge zur Bereitstellung digitaler Inhalte, p. 147 ff., 219 ff.; Loos, M B M (2011), p. 45-48; Bach, I (2019), p. 1705 ff.; Carvalho, J M (2019), p. 194 ff.; Spindler, G, Sein, K (2019), p. 415 ff.; Synodinou, T E (2020), Geoblocking in EU Copyright Law: Challenges and Perspectives, p. 136 ff.; Oprysk, L, Sein, K (2020), p. 594 ff.

2 European Commission (2015) Communication from the Commission to the European Parliament, the Council, the European Economic and Social Committee and the Committee of the Regions. A Digital Single Market Strategy for Europe from 6.5.2016, COM (2015) 192 final, p. 5; Arnerstål, S (2015), p. 882; Helberger, N et al. (2013), p. 42.

3 Loos, M B M et al. (2011), p. 14, 39, 102; Lehman, M In De Franceschi, A (2016), p. 115; Schulze, R In De Franceschi, A (2016), p. 131; Oprysk, L, Sein, K (2020), p. 597.

4 European Commission (2011) Communication from the Commission to the European Parliament, the Council, the European Economic and Social Committee and the Committee of the Regions: A Single Market for Intellectual Property Rights/Boosting creativity and innovation to provide economic growth, high quality jobs and first class products and services in Europe from 24.5.2011, COM(2011) 287 final, p. 8, 11; COM (2015) 192 final, p. 57, 20; European Commission (2016) Commission Staff Working Document: Evaluation of the Council Directive 93/83/EEC on the coordination of certain rules concerning copyright and rights related to copyright applicable to satellite broadcasting and cable retransmission from 14.9.2016, SWD (2016) 308 final. 
institutions; ${ }^{8}$ or (iv) legislation on audio-visual media suppliers. ${ }^{9}$ Last but not least, it is necessary to set forth rules for $(\mathrm{v})$ consumer protection in the digital market, ${ }^{10}$ and in this regard to focus on the (vi) aspects of the cross-border availability of the digital content. ${ }^{11}$

The aim of this paper is to analyse possible convergences and divergences of two legislative acts: the Portability Regulation [Regulation (EU) No. 2017/1128] and the Digital Content Directive [Directive (EU) No. 2019/770]. The Digital Content Directive expressly states: "It should also be without prejudice to Union and national law on copyright and related rights, including the portability of online content services" (Recital 36 Digital Content Directive). This provision means that the Directive does not change any provisions in the Portability Regulation. However, we must ask what the relationship is between these two pieces of legislation when they regulate similar subject matter.

We will focus specifically on the rights of consumers who use digital content in other EU Member States than their Member State of residence ${ }^{12}$.

5 Regulation (EU) 2016/679 of the European Parliament and of the Council of 27 April 2016 on the protection of natural persons with regard to the processing of personal data and on the free movement of such data, and repealing Directive 95/46/EC (General Data Protection Regulation); Directive (EU) 2016/680 of the European Parliament and of the Council of 27 April 2016 on the protection of natural persons with regard to the processing of personal data by competent authorities for the purposes of the prevention, investigation, detection or prosecution of criminal offences or the execution of criminal penalties, and on the free movement of such data, and repealing Council Framework Decision 2008/977/JHA.

6 Art. 17 Directive (EU) 2019/790 of the European Parliament and of the Council of 17 April 2019 on copyright and related rights in the Digital Single Market and amending Directives 96/9/EC and 2001/29/EC.

7 Directive 2014/26/EU of the European Parliament and of the Council of 26 February 2014 on collective management of copyright and related rights and multi-territorial licencing of rights in musical works for online use in the internal market.

8 Art. 3 - 7 Directive 2019/790/EU.

9 Directive (EU) 2019/789 of the European Parliament and of the Council of 17 April 2019 laying down rules on the exercise of copyright and related rights applicable to certain online transmissions of broadcasting organisations and retransmissions of television and radio programmes, and amending Council Directive 93/83/EEC; Directive (EU) 2018/1808 of the European Parliament and of the Council of 14 November 2018 amending Directive 2010/13/EU on the coordination of certain provisions laid down by law, regulation or administrative action in Member States concerning the provision of audiovisual media services (Audiovisual Media Services Directive) in view of changing market realities.

10 Directive (EU) 2019/770 of the European Parliament and of the Council of 20 May 2019 on certain aspects concerning contracts for the supply of digital content and digital services.

11 Regulation (EU) 2017/1128 of the European Parliament and of the Council of 14 June 2017 on cross-border portability of online content services in the internal market. See also Hoffman, J (2016), p. 145; Mazziotti, G (2016), p. 365 ff.; Trimble, M (2016), p. 45 ff; Engles, S; Spindler, G (2016) Die Modernisierung des europäischen Urheberrechts Der Vorschlag zur Portabilitäts-VO und die Planungen der EU-Kommission, p. 73 ff.; Nordemann, J B (2018), p. $179 \mathrm{ff}$.

12 Recital 3, Art. 1 (1), Art. 2 (4) Portability Regulation. 
Nevertheless, we will also address the cross-border portability in the framework of possible EU unitary copyrights. In this context, we will explain that the use of geo-blocking practices is not primarily a question of the existence of unitary rights as has been argued by some scholars, ${ }_{1}^{13}$ but a question of the contractual limits imposed on the practices of digital content providers.

Digital Content Directive regulates certain aspects of contracts on the supply of digital content and digital content services between content providers and consumers. With the Digital Content Directive, the EU is responding to the needs of the digital economy in the area of private law. The EU legislator justifies the adoption of the new legislation, in particular by facilitating access to digital content and digital services, developing the European Union's digital economy and stimulating overall growth. One of the factors affecting cross-border trade in the European Union is differences in national contract law and the uncertainty as to the legal regime applicable to transactions related to digital content and services.

The directive pursues a viable and a technology-oriented approach. Its provisions regulate all categories of digital content or services and highlights the necessity of consumer protection also in situations where the consumer's performance is not based on monetary payments but on providing personal data ${ }^{14}$. Moreover, the directive intends to regulate consumer rights in case the digital content or service is not in conformity with the contract and stipulates consumer rights and remedies.

For consumers, a current state means uncertainty about fundamental contractual rights, which negatively affects their confidence in cross-border trade. For enterprises, the uncertainty means especially additional costs for legal services. Harmonization of fundamental contractual rights should motivate consumers to purchase more cross-border digital content, and businesses, especially SMEs, to expand across borders. The Digital Content Directive is strongly inspired ${ }^{15}$ by the provisions of the Commission's proposal for a Regulation on a Common European Sales Law (hereinafter

13 Hoffmann, J (2016), p. $168 \mathrm{ff}$.

14 According to Art. 3 (1) Digital Content Directive this directive shall also apply where the trader supplies or undertakes to supply digital content or a digital service to the consumer, and the consumer provides or undertakes to provide personal data to the trader. Thus, the directive also comprises a new business model called "performance against data." However, the data must be classified as a consideration, which means that the trader is not processing data to fulfil his/her contractual or legal obligations. See also Carvalho, J M (2019), p. 197; Bach, I (2019), p. 1706; Spindler, G, Sein, K. (2019), p. 418; Lehmann, M In De Franceschi, A (2016), p. 117. 
"CESL") ${ }^{16}$ which was intended to constitute an optional instrument that would actually create a parallel contract-law regime to coexist alongside national contract-law provisions. ${ }^{17}$

Together with the Geoblocking Regulation, ${ }^{18}$ the Portability Regulation represents an essential tool for ensuring the cross-border portability and prohibits the implementation of geo-blocking measures ${ }^{19}$ within the EU Digital Single Market. This should enable the digital content consumers who subscribed to content services in the Member State of their permanent residence to receive a service or a download of pre-paid content, in a country, which they are temporarily visiting. In addition, the Portability Regulation aims to prevent consumers from infringing copyright on digital content, $^{20}$ which is frequently caused by the unavailability of the protected subject-matter due to the application of geo-blocking practices by some content providers.

15 COM (2015) 634 final, p. 2; Lehmann, M In De Franceschi, A (2016), p. 113; Spindler, G, Sein, K. (2019), p. 415.

16 In October 2011, the European Commission issued a proposal for the Common European Sales Law (CESL) which was intended to give traders the choice to sell their products to customers in another Member State on the basis of a single set of contract law rules that would stand as an alternative to the national contract law of each Member State. The CESL project [also called the "Blue-Button Project"; Schulte-Nölke, H (2011), p. 89] was intended to be an autonomous set of private-law rules parallel to the national laws of EU Member States. Thus it should not represent the European private law in the sense of choice-of-law rules such as the Rome I or Rome II Regulation, but an optional instrument suitable for both B2C and B2B relationships that could be chosen by contracting parties as a set of directly applicable legal rules regulating the specific contractual relationships. CESL should be applied as a "twenty-eighth legal order" which complement the laws of the EU Member States, but only if the contracting parties explicitly made a choice of this legal instrument (opt-in principle). During the discussions in the Council and the European Parliament, the European Commission finally decided to withdraw the CESL proposal on the grounds that a new proposal would cover only the e-commerce aspects in the Digital Single Market. The reasons for the withdrawal of the CESL proposal were substantial. In particular, the United Kingdom expressed strong reservations regarding the inconsistency of the proposal with the common-law. See also Scottish Law Commission (2011) An Optional Common European Sales Law: Advantages and Problems Advice to the UK Government, The Law Commission and The Scottish Law Commission [online]; Lehmann, M In De Franceschi, A (2016), p. 113; Schulze, R In De Franceschi, A (2016), p. 128.

17 Beale, H (2013), p. 22 ff; Twigg-Flesner, Ch (2013), p. 45 ff.; Schulze, R (2012), p. 85 ff.; Pongelli, G (2013), p. 11 ff., 17.

18 In this paper, we do not deal with the impact of the Geoblocking Regulation [Regulation (EU) 2018/302 of the European Parliament and of the Council of 28 February 2018 on addressing unjustified geo-blocking and other forms of discrimination based on customers' nationality, place of residence or place of establishment within the internal market and amending Regulations (EC) No 2006/2004 and (EU) 2017/2394 and Directive 2009/22/EC] on the Digital Content Directive. Given the material scope of the Geoblocking Regulation [Art. 3 Regulation (EU) 2018/302], it seems that the relationship between these two pieces of EU legislation is similar to that of the Portability Regulation discussed in this paper. However, a more detailed analysis would require drafting a separate research paper.

20 COM (2015) 626 final, p. 4, 11. 
Both pieces of legislation address similar issues related to consumers' expectations of being able to use digital content effectively without technological, functional or cross-border limitations. The question of cross-border portability is a principal subject matter of Art. 3 (1) Portability Regulation, and can also be considered as an issue of "accessibility" within the scope of the "conformity of the digital content with the contract" [Art. 8 (1) (b) Digital Content Directive].

It is evident that the Digital Content Directive regulates a more comprehensive range of legal relationships. The reason for this is that it applies to all contracts with digital content and services and is targeted not only at cross-border relationships, but also in situations where the content provider supplies the digital content to consumers within the territory of a particular Member State. Although the directive itself does not intend to regulate any intellectual property issues [Art. 3 (9) Digital Content Directive], the directive will have a direct impact on copyright licences or other types of the end-users contracts. ${ }^{21}$

Compared to the broad spectrum of consumer issues regulated by the Digital Content Directive, the Portability Regulation constitutes new consumer (subscriber) rights for when a consumer uses digital services in a Member State of their "temporarily presence" [Art. 2 (4), Art. 4 Portability Regulation]. ${ }^{22}$ While the Digital Content Directive applies to both domestic and cross-border transactions, the Portability Regulation only applies to cross-border delivery of on-line digital goods or services. On the other hand, the Portability Regulation prescribes rules which are immediately applicable not only to the service providers, but simultaneously to copyright holders. The EU legislator is aware that blocking practices are broadly asserted by the major copyright

${ }^{21}$ Many service providers of digital content use contractual terms in which the user receives a limited licence to use the digital content. If you subscribe to Spotify, Netflix, iTunes or Google-Play, you enter into a licence or service agreement, not a purchase agreement. For example, in its Terms and Conditions, Netflix grants to end-users "a limited, non-exclusive, revocable, non-sublicensable and non-transferable license to display the Netflix Assets" (Netflix Media Center Terms and Conditions). The content providers keep the intellectual property rights and provide the consumer a limited, non-exclusive, revocable licence to make personal, non-commercial use of the digital content. See Arnerstål, S (2015), p. 752; Loos, M B M et al. (2011), p. 14; Oprysk, L, Sein, K (2020), p. 595 ff. The impact of the Digital Content Directive on licence or service contracts will consist in definition of digital content, its integration into the consumer's digital environment, but especially in the regulation of the rights the consumer has if the digital content is not in conformity with the licence or service contract.

22 Engles, S; Nordemann, J B (2018), p. 193. 
or by the related rights holders, and therefore he limits their contractual freedom about the supply of the digital content to end-users. ${ }^{23}$

The key question that this paper aims to answer is whether a consumer will be entitled to pursue claims arising from the non-conformity of digital content with the contract, as provided by Art. 8 and 14 of the Digital Content Directive, in the event that he or she is not allowed to access digital services in states other than the Member State of his or her residence due to the application of geo-blocking measures by digital content providers. If the answer to this question is yes, we will then focus on the hierarchy of remedies provided to the consumer in the event the digital content does not conform to the contract (Art. 14 Digital Content Directive), as well as on issues related to the quality of content transmitted to the subscriber under Art. 3 of the Portability Regulation. When analysing the Portability Regulation, we will also discuss whether the European Commission should propose uniform copyright protection under Art. 118 TFEU rather than ensuring cross-border portability. However, we will defend the thesis that ensuring cross-border portability by Art. 3 (1) of the Portability Regulation and also by the prohibition of geo-blocking via provisions of the Regulation $2018 / 302 / \mathrm{EU}^{24}$ is the appropriate legislative tool to enable the subscriber to enjoy the cross-border use of the digital content. ${ }^{25}$

${ }^{23}$ COM (2015) 627 final, p. 2, 4; Recitals 10 and 29 Portability Regulation.

24 Regulation (EU) 2018/302 of the European Parliament and of the Council of 28 February 2018 on addressing unjustified geo-blocking and other forms of discrimination based on customers' nationality, place of residence or place of establishment within the internal market and amending Regulations (EC) No 2006/2004 and (EU) 2017/2394 and Directive 2009/22/EC.

25 Differently see Hoffmann, J (2016), p. 169 ff. 


\section{THE MATERIAL SCOPE OF THE DIGITAL CONTENT DIRECTIVE}

After the CESL proposal was withdrawn, ${ }^{26}$ the Commission decided to abandon the comprehensive "optional instrument approach". ${ }^{27}$ The proposal for the Digital Content Directive was presented by the Commission in December 2015 and was submitted according to Art. 114 TFEU. The Commission's aim was to adopt a fully harmonizing directive (Recital 6, Art. 4 Digital Content Directive) instead of the comprehensive regulation. Thus, the Digital Content Directive represents targeted ${ }^{28}$ legislation which harmonizes mandatory consumer contract-law rules.

Although the Consumer Rights Directive ${ }^{29}$ has fully harmonized certain rules for the online supply of digital content (especially pre-contractual information and the rules related to the right of withdrawal), ${ }^{30}$ there were almost no specific EU rules to protect consumers if the digital content does not fulfil the requirements of functionality, interoperability, or accessibility. ${ }^{31}$

${ }^{26}$ The CESL proposal has never received approval by the Council (see Fn. No. 16). On 16. 12. 2014, the Commission officially placed the CESL on the list of proposals intended to be modified or withdrawn. Later, on 9. 12. 2015, the Commission presented a modified text that would harmonize contract rules for the supply of digital content and the online sales of goods. See European Commission (2014) Communication from the Commission to the European Parliament, the Council, the European Economic and Social Committee and the Committee of the Regions. Commission Work Programme 2015. A New Start, from 16. 12. 2014, COM (2014) 910 final; European Commission (2015) Communication from the Commission to the European Parliament, the Council, the European Economic and Social Committee. Digital contracts for Europe - Unleashing the potential of e-commerce from 9. 12. 2015, COM/2015/0633 final; See also Clive, E (2015).

27 European Commission (2015) Impact Assessment: Proposals for Directives of the European Parliament and of the Council (1) on certain aspects concerning contracts for the supply of digital content and (2) on certain aspects concerning contracts for the online and other distance sales of goods from 17.12.2015. SWD (2015) 274 final/2, p. 52.

28 Beale, H (2016). p. 8; Lehmann, M In De Franceschi, A (2016), p. 115; Schulze, R In De Franceschi, A (2016), p. 135; Spindler, G, Sein, K. (2019), p. 415.

29 Art. 5, Art. 9 and Art. 14 Directive 2011/83/EU of the European Parliament and of the Council of 25 October 2011 on consumer rights, amending Council Directive 93/13/EEC and Directive 1999/44/EC of the European Parliament and of the Council and repealing Council Directive 85/577/EEC and Directive 97/7/EC of the European Parliament and of the Council.

30 Art. 6 and 9 Consumer Rights Directive; See also Beale, H (2016), p. 6; Carvalho, J M (2019), p. 194.

31 For digital content, there were just minimum requirements regulated by the Unfair Contract Terms Directive [Art. 3, 4 (2) Council Directive 93/13/EEC of 5 April 1993 on unfair terms in consumer contracts]. Another standard was set by the Consumer Sales and Guarantees Directive (Art. 2 and 3 Directive 1999/44/EC of the European Parliament and of the Council of 25 May 1999 on certain aspects of the sale of consumer goods and associated guarantees), but just with regard to "tangible movable items" [Art. 1 (2) b) Directive 1999/44/EC] such as CDs or DVDs. 
The Digital Content Directive has an extensive scope, which is to be applied on various categories of contracts regarding digital supply. ${ }^{32}$ Such a broad scope of application is one of the important differences ${ }^{33}$ from the Contracts for the Sale Directive, ${ }^{34}$ which employs merely the contract of sales [Art. 1, Art. 2 (a) Contracts for the Sale Directive]. The Digital Content Directive also does not distinguish between the categories of digital content or digital services (Recital 19 Digital Content Directive), because such differentiation in the field of rapidly evolving technologies would probably lead to discrimination between suppliers. Therefore, all kinds of data, copyrighted works (films, music, photos, computer games), as well as all possible forms of digital content provided by consumers (blogs, discussion forums, text-based collaboration formats etc.) are covered by the material scope of the directive, ${ }^{35}$ no matter if they are available on-line or if the digital content is contained on CDs or DVDs. ${ }^{36}$

In a similarly broad manner, the EU regulates types of contracts with regard to counter performance. The directive treats contracts in which a consumer provides personal data as contracts for consideration [Recital 24, Art. 3 (1) Digital Content Directive]. Although the consumer receives digital content from the supplier "for free", if he or she gives access to his

32 Spindler, G, Sein, K (2019), p. 415.

${ }_{33}$ Zoll, F (2016), p. 251; Spindler, G (2016) Verträge über digitale Inhalte, p. 147.

34 Directive (EU) 2019/771 of the European Parliament and of the Council of 20 May 2019 on certain aspects concerning contracts for the sale of goods, amending Regulation (EU) 2017/2394 and Directive 2009/22/EC, and repealing Directive 1999/44/EC. Directive 2019/771/EU and Directive 2019/770/EU should complement each other. While Directive 2019/770/EU (Digital Content Directive) lays down rules on certain requirements concerning contracts for the supply of digital content or digital services, the Directive 2019/771/EU (Contracts for the Sale Directive) lays down rules on certain requirements concerning contracts for the sale of goods. Accordingly, Directive 2019/770/EU applies to the supply of digital content or digital services, including digital content supplied on a tangible medium, such as DVDs, CDs, USB sticks and memory cards, as well as to the tangible medium itself, provided that the tangible medium serves exclusively as a carrier of the digital content. In contrast, the Directive 2019/771/EU should apply to contracts for the sale of goods, including goods with digital elements which require digital content or a digital service in order to perform their functions [Recital 13, Art. 3 (3) Contracts for the Sale Directive].

35 However, the Directive does not apply to digital content, which is embedded in goods in such a way that it operates as an integral part of the goods and its functions are subordinated to the main objective of the goods (Recital 21 Digital Content Directive). Thus, toys which contain music or even audio-visual clips will fall outside the scope of the Digital Content Directive, even though they contain digital content. Goods with incorporated digital content fall under Article 3 (3) Contracts for the Sale Directive.

36 According to Recital 20 and Art. 3 (3) of the Digital Content Directive it is irrelevant whether the supply of digital content is carried on data carriers such as CDs or DVDs or through the downloading or streaming accessible via Internet. This is an important clarification, as the data carriers will not fall under the Contracts for the Sale Directive, including provisions on conformity with contract, rules on the burden of proof etc. 
or her personal or other data, the contracts will fall under the material scope of the directive. ${ }^{37}$

Finally, the directive is not intended to have any effect on copyright issues [Recital 36, Art. 3 (9) Digital Content Directive], especially on the distribution right applicable to digital goods under the copyright law (Recital 20 Digital Content Directive). Thus, all questions concerning digital rights management systems, as well as the effects of the principle of exhaustion, are omitted. The consumer therefore cannot argue that the limitations on further use of the digital content (such as the re-sale or lending of e-books) are not in conformity with the contract since the consumer, upon receiving the digital content, is not entitled to further distribution of the copyrighted content due to the copyright limitations, which are still applicable. ${ }^{38}$

The Digital Content Directive also has no direct application on relations between consumers and copyright holders. ${ }^{39}$ It only regulates the legal responsibilities of digital content providers who, as legal entities, are usually different from subjects that are the original or derivative holders of the copyright. With regard to the on-line dissemination of copyrighted works uploaded to the Internet by third parties, the Digital Content Directive stipulates that "where a restriction resulting from a violation of any right of a third party, in particular intellectual property rights, prevents or limits the use of the digital content or digital service in accordance with Articles 7 and 8, Member States shall ensure that the consumer is entitled to the remedies for lack

37 On the other hand, the directive does not apply if the data collected from the consumer are necessary for the "performance of the contract" or "for meeting legal requirements" [Art. 3 (1), Recital 25 Digital Content Directive]. The Directive is applicable only to that extent where the personal data are actively required by the provider and does not cover situations where the digital content is provided for free and data collected from the consumer are used only for security or registration purposes. Moreover, automatically generated personal data such as IP addresses or data collected and transmitted by means of cookies, without the consumer actively supplying it, also do not fall under the material scope of the directive. However, Member States may, on an optional basis, provide that the Directive also applies to such cases (Recital 25 Digital Content Directive). Similarly, situations in which the consumer is exposed to advertisements in order to gain access to digital content do not fall under the material scope of the directive. For criticism on the exclusion of cookie-based services like Google Analytics see Spindler, G (2016). Verträge über digitale Inhalte, p. 149; Beale, H (2016) Scope of application and general approach of the new rules for contracts in the digital environment, p. 13.

38 Critical remarks on this approach are by expressed by Beale. Beale, H (2016), Scope of application and general approach of the new rules for contracts in the digital environment, p. 27. Oprysk and Sein conclude that specific contractual arrangements that prohibit, for example, backups or file sharing outside the user's family, may be contrary to reasonable consumer expectations within the meaning of Art. 8 (1) (b) Digital Content Directive. Oprysk, L, Sein, K (2020), p. 620.

39 Spindler, G (2016), Verträge über digitale Inhalte, p. 149. 
of conformity provided for in Article 14, unless national law provides for the nullity or rescission of the contract for the supply of the digital content or digital service in such cases". After the implementation of the Digital Content Directive into the national legislation of the EU Member States, the intermediaries, who request payments for the use of digital content or who require personal data from the consumer, will have to provide a legal guarantee to the consumer that the digital content is in conformity with the contract, especially that it does not conflict with the intellectual property rights of third parties ("third party rights" or "legal nonconformity"). ${ }^{40}$

The Digital Content Directive uses positive [Art. $3(1-3),(6)]$ and negative definitions [Art. 3 (4), (5), (10)] for the determination of its material scope. In this regard, Art. 3 (7) of the Digital Content Directive stipulates: "If any provision of this Directive conflicts with a provision of another Union act governing a specific sector or subject matter, the provision of that other Union act shall take precedence over this Directive". In relation to portability, the Directive then specifically provides that: "It should also be without prejudice to Union and national law on copyright and related rights, including the portability of online content services" (Recital 36 Digital Content Directive).

If we focus on the relation between the "conformity with the contract" and the "portability matters", it seems necessary to analyse whether Art. 3 (7) of the Digital Content Directive sets the rule on the negative scope of the directive, and therefore all the issues regulated by the special legislation are excluded from the scope of the Digital Content Directive, or whether this provision contains only a specialty rule. The specialty rule would mean that the Portability Regulation would be applied only to the extent to which it regulates the "specific sector or subject matter", such as the availability of digital content in the Member State of the temporary presence of the consumer, but other issues, such as remedies concerned with the non-availability of digital content, would fall under the scope of the national laws transposing the provisions of the Digital Content Directive.

\footnotetext{
${ }^{40}$ Oprysk, L, Sein, K (2020), p. 598. See also Recital 54 Digital Content Directive.
} 


\section{PORTABILITY OF DIGITAL CONTENT AS A CONSUMER-LAW ISSUE}

From the perspective of consumer protection, which is more stressed by the Digital Content Directive ${ }^{41}$ than by the Portability Regulation, ${ }^{42}$ we should return to the question of what the relation between these two pieces of EU legislation is.

Portability and geo-blocking are two different sides of the same coin. ${ }^{43}$ While portability is positively characterized as the ability "to play, listen, and watch digital content on different kinds of devices, to lock-in or lock-out situations that are the result of product bundling or interoperability issues, social exclusion, and geographical impediment because of region coding and restrictive licencing practices", ${ }^{44}$ the notion of geo-blocking is primarily negative, ${ }^{45}$ as it is used by copyright holders or digital content providers to block foreign IP addresses ${ }^{46}$ in order to prevent consumers from having cross-border access to digital content services. ${ }^{47}$

Portability reflects consumers' natural expectations that the digital content, which covers many kinds of "intangible assets", will be available across borders and ubiquitous. If consumers complain ${ }^{48}$ about territorial restrictions on the broadcasting of copyrighted works or sporting events applied by the suppliers, we can remark that consumers are merely applying their "common sense". They see no relevant reason for the lack

41 Consumer law and copyright law deal with digital content from opposing positions. While consumer law focuses on the ownership of the purchased items or the right to use them under reasonable expectations of the consumer, copyright law considers digital content from the owners' perspective and especially highlights that ownership of a physical copy of a work does not grant any ownership in the copyright itself. Helberger N et al. (2013), p. 46; Loos, M B M (2011), p. 30, 31; Oprysk, L, Sein, K (2020), p. 597.

42 Engles, S; Nordemann, J B (2018), p. 179.

43 SWD (2015) 270 final, see Fn. 7 at p. 3.

${ }_{44}$ Helberger, N et al. (2013), p. 40. Similarly Synodinou, T E (2020), Geoblocking in EU Copyright Law: Challenges and Perspectives, p. 144; Engles, S; Nordemann, J B (2018), p. 182.

45 However, geo-blocking may also have a positive role in the digital environment. While Hoffmann points to the negative aspects of geo-blocking, such as language discrimination, consumer frustration or the obstacles to create a Digital Single Market [Hoffmann, J (2016), p. 145], Trimble on the other hand argues that geo-blocking also plays important roles in the Internet legal landscape. Geo-blocking serves as a tool for delimiting jurisdiction and enforcing decisions within territorial boundaries; it serves the purposes of enhancing security and partitioning markets, and also enables compliance with territorially-defined laws (such as privacy and personal data protection). See Trimble, M (2016), p. 47-50.

46 Other methods of controlling the Internet users' geographical location may also be used, such as global positioning system (GPS). Trimble, M (2012), p. 605. For simplicity, in this paper we will only use geo-location based on the IP address.

47 SWD (2015) 270 final, p. 39, 58; Trimble, M (2016), p. 46; Hoffmann, J (2016), p. 145.

48 SWD (2015) 270 final, p. $54 \mathrm{ff}$. 
of availability of digital content in the Digital Single Market ${ }^{49}$ (or even in the global market), even though they know nothing about the theoretical aspects of intangible assets. The consumers argue that if the EU developed a Single Market in the sphere of physical goods or services, similarly they should have on-line access to the digital content throughout the EU. The digital content should be lawfully accessible not only in the Member State of the consumer's permanent residence, but also when travelling to another EU Member State. ${ }^{50}$ Moreover, the natural characteristics of intangible assets (as well as the expectations of consumers) are highlighted by the fact that the Internet has been developed as a medium available and accessible without physical boundaries. ${ }^{51}$

In the past, with the exception of films and sporting events, ${ }^{52}$ providers in EU countries did not generally impose territorial restrictions on digital content. Even though there could have been cultural and economic (i.e. protecting the investments of film producers) reasons for the territorial division of markets, ${ }^{53}$ most digital assets (i.e. musical works, computer programs or e-books) were provided without border restrictions. From the consumers perspective it was hardly justifiable ${ }^{54}$ that audio-visual producers or broadcasting organizations so strongly insisted on a territorial-based dissemination of digital assets. We can compare how copyrighted works have quite recently been provided around the EU with a federal state such as Germany. It was doubtful that a broadcaster provided a territorially limited licence to a German citizen solely for Free State Bavaria. The end-users in Germany were allowed to watch a Bayern Munich football match

49 SWD (2015) 270 final, p. 3, 6. However, for opposite views concerning the defence of geoblocking activities based on the protection of investment of film producers and cultural differences among EU Member States see Mazzotti, G (2016), p. 369 ff.

50 SWD (2015) 270 final, p. 6; Engles, S, Nordemann, J B (2018), p. 184.

51 Trimble, M (2012), p. 570; Trimble, M (2016), p. 147.

52 SWD (2015) 270 final, p. 8-10, 39.

53 Mazzotti, G (2016), p. 373-375. Another reason for the application of the geo-location techniques are provided by Trimble. She explains that geolocation reflects the territorial based legal regulations not just in the area of IP, but also with respect to the personal data protection. Moreover, it enables the supplier to provide the tailored content, included differential pricing, localizing advertising, and Internet searching. Trimble, M (2012), p. 586, 589.

54 Cross-border portability has been considered to be a modern distribution tool not only by consumers, but also by the audio-visual industry. In 2013, several members of the audiovisual industry have adopted the joint statement at the Licences for Europe forum where they confirmed that they were prepared to work on cross-border portability in the EU. See Licences for Europe - Structured Stakeholder Dialogue 2013, WG 1 Audio-visual Subgroup, Joint Statement on Cross-border Portability of lawfully-acquired Audio-visual Content [online]. 
in Dresden because the geo-blocking restrictions have not been applied. Thus, the arguments based on the economic models ${ }^{55}$ or film distribution among EU Member States were not convincing, since the dissemination model could hardly prevail over the basic principles of the EU single market such as free movement of goods and services [Art. 26 (2), Art. 56 TFEU] and over consumer protection [Art. 12, Art. 114 (3), Art. 169 TFEU]. Even though the problem of the territorial scope of copyright protection could probably be efficiently solved by the adoption of the EU-wide Copyright Regulation (adopted under Art. 118 TFEU, which would create unitary EU copyright protection), ${ }^{56}$ the real effects of the Portability Regulation showed that the accessibility has not been question of the unitary rights but about the removal of territorial barriers in the sphere of contract law. ${ }^{57}$ The problem is that under the regime of unitary rights, we may still find examples in which licences are granted not across the entire territory of the EU, but in several states only. For example, Council Regulation No. 2017/1001 of 14 June 2017 on the European Union trade mark expressly enables the trademark owner to grant a licence for the "whole or part of the EU". ${ }^{58}$ Although it is hard to presume that the example on the territorial limits of broadcasting in Germany would actually happen, it may still be possible under the EU Copyright Regulation to provide licences on a territorial basis, unless such a possibility is expressly forbidden by the legislation.

The Portability Regulation is usually analysed in terms of copyright protection, ${ }^{59}$ underlying the principle of territoriality. However, portability is not primarily a question of the territoriality of the copyright but a question of the licencing policy of copyright holders. ${ }^{60}$ Consistent with the holdings of the CJEU in the Football Association Premier League

\footnotetext{
55 Mazzotti, G (2016), p. 371. See also SWD (2015) 270 final, Annex 4.

56 Hoffmann, J (2016), p. 166 ff.; Mazzotti, G (2016), p. 375.

57 Peifer, K, N In De Franceschi, A (2016), p. 166.

58 The same rule applies also to the Community Designs [Art. 32 (1) Council Regulation (EC) No 6/2002 of 12 December 2001 on Community designs] and on the future European Patent with the unitary effect [Art. 3 (2) Regulation (EU) No 1257/2012 of the European Parliament and of the Council of 17 December 2012 implementing enhanced cooperation in the area of the creation of unitary patent protection].

59 Hoffmann, J (2016), p. 145, 149 ff.; Mazotti, G (2016), p. 367,368; Engles, S; Nordemann, J B (2018), p. $180 \mathrm{ff}$.

60 Arnerstål, S (2015), p. 752; Synodinou, T E (2020), EU Internet Law: Regulation and Enforcement, p. 38.
} 
decision$^{61}$ the Portability Regulation does not tackle the territoriality of copyright protection ${ }^{62}$ but the discriminatory geo-blocking practices applied by copyright holders or digital service providers. The obligation stipulated by Art. 3 (1) of the Portability Regulation that enables a subscriber who is temporarily present in a Member State to access and use the online content services makes the contract law in EU Member States "cross-border and consumer friendly". ${ }^{63}$ Portability as a limit on the contractual freedom of copyright holders might be seen as a more efficient way to fulfil consumer expectations, since even under the regime of EU unitary copyright, digital content may still be distributed on a territorial basis. ${ }^{64}$ It is for this reason that digital content providers may grant licence for a part of the territory and use the consumer's IP address as an identifier to control for the territorial scope of the licence. Although it has been indicated by some authors that geo-blocking practices reflect the territorial character of copyright protection, ${ }^{65}$ when we consider consumer protection and the related contractual issues, they seem to be caused more by the licencing policy of the digital content providers than they are by the traditional principles of copyright.

61 Judgment of the Court (Grand Chamber) of 4 October 2011 Football Association Premier League Ltd and Others v QC Leisure and Others (C-403/08) and Karen Murphy v Media Protection Services Ltd (C-429/08).

62 As has been described above, copyrighted works such as musical works, software and ebooks have been distributed on an EU-wide basis and the end user licence agreements granted to consumers the right to use the copyrighted content in all EU Member States even though 27 different copyright regulations still existed.

63 SWD (2015) 274 final/2, p. 18.

${ }^{64}$ Digital content provider activities would probably be analysed also from EU competition law perspectives. Mazzoti points out the competition law issues when focusing on the CJEU in the Premiere League case. In this regard he remarks that restrictions to competition in the field of providing services might be justified by objective criteria. Therefore the creation of barriers to cross-border accessibility of services can be justified for example by supporting cultural creations targeted at national audiences [Mazotti, G (2016), p. 373]. Even though the EU competition law applies different criteria for assessing service provider activities than the consumer law does, the author of this paper is of the opinion that both fields of EU law converge in the regulation of portability issues. If the EU declares that geoblocking activities are unfair, that they conflict with consumer expectations and that they create serious obstacles to creating a Digital Single Market (Recital 4 Portability Regulation; SWD (2015) 270 final, p. 3), then the limitations on the licencing policy might be set by the competition law as well. For example, the Commission Regulation (EU) No 316/2014 of 21 March 2014 on the application of Article 101(3) of the Treaty on the Functioning of the European Union to categories of technology transfer agreements sets limits on the licencing policy of the owners of essential patents, while they are forced to apply the FRAND licences (fair, reasonable and non-discriminatory) on a non-exclusive basis. The main rationale of the Portability Regulation is the same, since it imposes limits on the licencing policy of copyright holders and the providers of digital content.

65 Hoffmann, J (2016), p. 151 


\section{PORTABILITY AS A SUBCATEGORY OF CONFORMITY WITH THE CONTRACT}

The central role of EU consumer law is to function as corrective justice ${ }^{66}$ and to protect the weaker party. ${ }^{67}$ Contractual dealings between consumers and suppliers must respect the legitimate interests of both parties and must reflect a fair balance between their legitimate interests. When assessing the fairness of consumer transactions, it is important to compare them with the principle of "reasonable expectation". If a product or service does not meet the reasonable expectations of the consumer, such as the availability of a product in the required time and place, then the contract can no longer be assumed to reflect the consumer's free will to commit to the transaction. ${ }^{68}$ In the event that a consumer cannot utilize a product in a way that corresponds to his or her reasonable expectations, we can find grounds under which the consumer can contest the conformity with the contract. ${ }^{69}$

There are two basic approaches to defining the concept of conformity: a subjective approach based on contractual agreements and an objective approach based on legally established conformity criteria. ${ }^{70}$ A third possibility would be a mixed approach which uses both criteria as applied, for example, in the Consumer Sales and Guarantees Directive, as well as in the Contracts for the Sale Directive. ${ }^{71}$ Art. 7 of the Digital Content Directive gives priority to the subjective approach but it also introduces the objective criteria in Art. 8.

As a general rule, the criteria used to assess conformity are the contractual stipulations which are "clearly and comprehensively" contained in the contract [Art. 12 (4) and (5) Digital Content Directive], or the conditions which are deemed to represent an integral part of the contract, such as pre-contractual information [Art. 7 (b) Digital Content Directive].

In the absence of explicit contractual provisions, or if the clauses are ambiguous Art. 8 (1) of the Digital Content Directive stipulates that the digital content or digital service shall be fit "for the purposes for which

\footnotetext{
66 Micklitz, H W (1999), p. 167 ff.

${ }^{67}$ Cherednychenko, O (2007).

68 Helberger, N, Hugenholtz, P B (2007), p. 1082.

69 Helberger, $\mathrm{N}$ et al. (2013), p. 45.

70 Staudenmayer, D (2016), p. 2722; Spindler, G (2016), Verträge über digitale Inhalte, p. 152.

${ }^{71} \operatorname{COM}$ (2015) 634 final, p. 12; SWD (2015) 274 final/2, p. 46.
} 
digital content or digital services of the same type would normally be used, taking into account, where applicable, any existing Union and national law, technical standards or, in the absence of such technical standards, applicable sector-specific industry codes of conduct". The objective test of conformity with the contract is then linked to other criteria such as "technical standards" or "applicable sector-specific industry codes of conduct" [Art. 8 (1) (a) Digital Content Directive].

Although the Digital Content Directive may be criticized for its lack of such norms and $\operatorname{codes}^{72}$ or for its emphasis on a supplier's ability to craft overly comprehensive contractual provisions to exclude the application of the objective test, in terms of portability requirements the Directive seems to be satisfactory. We may consider the Portability Regulation as a sui generis form of such regulatory treatment.

In practice we can identify three main conformity problems: (1) accessibility, functionality and compatibility issues, (2) insufficient quality, and (3) deficiencies, errors or other safety and security issues. ${ }^{73}$ These challenges can be caused by matters such as lack of connectivity, the application of DRM mechanisms which create obstacles for the transfer of digital content from one device to another, incompatibility of formats and standards, ${ }^{74}$ or even the abuse of the copyright protection when prohibiting the consumer from making private copies of lawfully acquired software or film. ${ }^{75}$

Portability $^{76}$ matters are primarily concerned with "accessibility requirements" [Art. 8 (1) (b) of the Digital Content Directive]. Geo-blocking practices are usually connected to the use of an Internet Protocol address to identify a consumer's location. When this happens, the consumer is hindered from accessing digital content/service or is re-routed to a local website with different products or pricing. ${ }^{77}$ Although such practices could

72 Spindler, G (2016), Verträge über digitale Inhalte, p. 153; Mak, C (2016), p. 16; Beale, H (2016), Scope of application and general approach of the new rules for contracts in the digital environment, p. 21. Art. 8 (1) was strongly influenced by Art. IV. A. - 2:302 DCFR and Articles 99 and 100 CESL.

73 Loos, M B M et al. (2011), p. 108.

74 Ibid, p. 109-113.

75 Helberger, N, Hugenholtz, P B (2007), p. 1093, 1095. Similarly see Oprysk, L, Sein, K (2020), p. $601 \mathrm{ff}$.

76 "'Portable' means a feature of an online content service whereby subscribers can effectively access and use the online content service in their Member State of residence without being limited to a specific location" [Art. 2 (6) Portability Regulation].

77 Hoffmann, J (2016), p. 145 
be in conformity with the licence conditions of the major digital content providers, they generate frustration for a great deal of consumers ${ }^{78}$ who cannot use their subscription services or the content they have previously purchased in other countries.

From the perspective of accessibility, both the Portability Regulation and Digital Content Directive aim at facilitating access to digital content and they seem to be complementary. Although the Digital Content Directive does not explicitly mention the cross-border portability of digital content, it is obvious that the reasonable expectations of consumers on the accessibility of digital content in other EU Member states are supported by the Portability Regulation and the Digital Content Directive as well.

For these reasons, a consumer's inability to access the digital content which was provided in their home Member State while he or she is temporarily located in another Member State is to be considered a breach of "conformity with the contract" according to the objective criteria test regulated by Art. 8 (1) of the Digital of the Content Directive.

We may conclude that the Portability Regulation should be considered as a special piece of legislation in terms of Art. 3 (7) of the Digital Content Directive. Thus, it only regulates specific issues related to the accessibility of digital content, however, areas such as burden of proof, consumer claims, rights of third parties, and remedy for the failure to supply are covered by the Digital Content Directive. Respectively, these consumer law issues will be regulated by provisions which will be adopted after the implementation of the directive into the national legal orders of the EU Member States.

In the following part of this paper we will focus on selected details of this special kind of non-conformity with the contracts. We will analyse whether the unenforceability provision adopted by the Portability Regulation is consistent with traditional terms which are used by legislators in the EU Member States for to express the invalidity of contracts. Next, we will concentrate on the hierarchy of remedies which the consumer may pursue if the performance is not in conformity with the contract. Finally, we will make a few remarks on the quality requirements of digital content provided by a service provider in a Member State that a consumer visits temporarily.

\footnotetext{
${ }^{78}$ SWD (2015) 270 final, p. 16.
} 


\section{SPECIFIC ISSUES RELATED TO THE BREACH OF CROSS-BORDER PORTABILITY}

When analysing specific relations between the Portability Regulation and the Digital Content Directive, we should first consider the differences in the terminology and the scope of both legislative acts. While the Digital Content Directive uses the terms "consumer"79 and "trader", ${ }^{80}$ the Portability Regulation deals with the consumer as a "subscriber" ${ }^{81}$ and it indirectly defines the "provider of the online content service" ${ }^{82}$ as the person providing audio-visual media services or other online services with protected subject matter, such as copyrighted works or broadcasting. The material and personal scope of the Digital Content Directive is broader because it also relates to the supply of offline digital assets such as the distribution of CDs or DVDs. The Portability Regulation is applicable only to online content services [Art. 1 (1) Portability Regulation].

Unlike the Digital Content Directive, the Portability Regulation concerns also those instances where digital content is provided for free and the provider requests personal data from the consumer only for the purposes of processing "for the purpose of supplying the digital content or digital service in accordance with this Directive or for allowing the trader to comply with legal requirements to which the trader is subject" [Art. 3 (1) Digital Content Directive].

Another difference between the legislative acts can be found in the presence of the cross-border element. While the Portability Regulation is applicable only in situations when the consumer uses the digital content in another Member State [Art. 2 (4), Art. 3 (1) Portability

79 "'Consumer' means any natural person who, in relation to contracts covered by this Directive, is acting for purposes which are outside that person's trade, business, craft, or profession" [Art. 2 (6) Digital Content Directive].

80 "'Trader' means any natural or legal person, irrespective of whether privately or publicly owned, that is acting, including through any other person acting in that natural or legal person's name or on that person's behalf, for purposes relating to that person's trade, business, craft, or profession, in relation to contracts covered by this Directive" [Art. 2 (5) Digital Content Directive].

81 "'Subscriber' means any consumer who, on the basis of a contract for the provision of an online content service with a provider whether against payment of money or without such payment, is entitled to access and use such service in the Member State of residence" [Art. 2 (1) Portability Regulation].

82 "'Online content service' means a service as defined in Articles 56 and 57 TFEU that a provider lawfully provides to subscribers in their Member State of residence on agreed terms and online, which is portable and which is: (i) an audiovisual media service as defined in point (a) of Article 1 of Directive 2010/13/EU, or (ii) a service the main feature of which is the provision of access to, and the use of, works, other protected subject-matter or transmissions of broadcasting organisations, whether in a linear or an on-demand manner" [Art. 2 (5) Portability Regulation]. 
Regulation], the Digital Content Directive regulates both the cross-border and the domestic relations which exist between the supplier of the digital content and the consumer. ${ }^{83}$

Further on in this paper we will explore situations in which digital content is provided (i) online, (ii) in exchange for money and (iii) in a Member State of the EU which is different from the state of the consumer's permanent residence. In these instances, both legislative acts would be applicable. ${ }^{84}$

\subsection{PORTABILITY AND UNENFORCEABILITY}

As has been explained above, both pieces of EU legislation overlap on the issue of accessibility to digital content or services. The Digital Content Directive subsumes accessibility under conformity with the contract [Art. 8 (1) (b) Digital Content Directive] and the Portability Regulation uses accessibility to define portability [Art. 2 (6) Portability Regulation]. We have also come to the conclusion that if an online content service, which is normally available to a subscriber in the Member State of his or her permanent residence, but can not be accessed in other EU Member States, it not only contravenes with Art. 3 (1) of the Portability Regulation, which entitles the consumer to have online access to digital content in other Member States, but also breaches the conformity with the contract.

Since the Portability Regulation requires providers to enable the crossborder portability of online content services [Art. 3 (1) Portability Regulation] and any contractual provision which does not comply with this requirement is unenforceable [Art. 7 (1) Portability Regulation], such legislative construction strongly affects the contractual law of EU Member

${ }^{83}$ COM (2015) 634 final, p. 10.

84 According to Art. 4 (3) TEU, and Art. 288 (3) TFEU, as well as the settled case-law of the CJEU, the courts of the Member States, are required to interpret national provisions in such a way as to achieve the objectives set by directives [so-called indirect effect of directives; see judgments of the CJEU in Von Colson and Kamann $v$ Land NordrheinWestfalen (C-14/83), Marleasing v. Comercial Internacional de Alimentación (C-106/89), Kolpinghuis Nijmegen (C-80/86)]. The national courts are, in principle, required to adopt such an interpretation in cases falling within the period after the transposition period of the directive has expired. However, such an interpretation is possible also before the expiry of the transposition period, but it is not the public authority's responsibility, and its admissibility depends on national law. Before the expiry of the transposition period the Member States courts are only required to refrain as far as possible from interpreting national law, which could seriously endanger the achievement of the objective pursued by the directive [CJEU in Konstantinos Adeneler and Others $v$ Ellinikos Organismos Galaktos (ELOG), C-212/04, para. 123]. 
States and brings new problems related to the fact that the EU Regulation declares certain categories of contractual provisions unenforceable.

If we examine other EU regulations we can see that the European legislator usually uses the term "null and void" 85 contract. This is based on the fact that almost all legal systems subsume provisions which breach mandatory legal rules under traditional categories of nullity (invalidity). ${ }^{86}$ Such provisions are automatically deemed invalid, as if they never existed. If material loss or immaterial damage arises in relation to the invalidity of a contract, the entitled person may claim damages for $\operatorname{loss}^{87}$ or request the return of the performance supplied under the contract. ${ }^{88}$

On the other hand, the term unenforceability has a different meaning in the majority of EU legal systems. Such unenforceable contractual provisions are not automatically invalid from the beginning, but they may not be enforced if the impaired party raises an objection of avoidance or relative nullity ${ }^{89}$ Only if such notice is addressed to the other contractual party, then the agreement is null from the beginning.

"Unenforceability" also refers to situations in which the contractual provision itself is valid, but it cannot be enforced. ${ }^{90}$ Provisions which are valid but may not be enforced by the creditor are called "natural obligations ${ }^{\prime \prime 11}$ in civil law jurisdictions. In fact, they represent merely a moral claim. $^{92}$

85 See for example Art. 7 (4) Regulation (EU) No. 492/2011 of the European Parliament and of the Council of 5 April 2011 on freedom of movement for workers within the Union; Art. 18 Regulation (EC) No. 392/2009 of the European Parliament and of the Council of 23 April 2009 on the liability of carriers of passengers by sea in the event of accidents. Similarly, Art. 101 (1) TFEU prohibits agreements between undertakings which have as their object or effect the prevention, restriction or distortion of competition within the common market and declares such prohibited agreements to be "automatically void" [Art. 101 (2) TFEU].

86 DCFR II.-7:302; Bar, von Ch, Clive, E, Schulte-Nölke, H (2009), p. 544 ff.

87 DCFR II.-7:304.

88 DCFR II.-7:303.

89 DCFR II. - 7:209; DCFR II. - 7:212. Most European legal systems stipulate that contracts violating mandatory legal rules are void. On the other hand, legal orders differ in the kinds of nullity and its effect. Belgian, Slovenian, Austrian, Czech and Slovak law distinguish between "absolute" and "relative nullity". Absolutely null and void contracts violate mandatory rules that aim at the protection of public interests. The nullity exists ipso jure which means that it is not necessary to invoke the invalidity before the court and the court should declare the voidance of the contract ex officio. In another EU Member States the situation is similar. Thus for example in France even "absolute nullity" must be claimed before the court and the judge may choose to raise the nullity. Bar, von Ch, Clive, E, Schulte-Nölke, H (2009), p. 570.

90 Bar, von Ch, Clive, E, Schulte-Nölke, H (2009), p. 3699. Similarly Engles, S; Nordemann, J B (2018), p. 195.

91 Bar, von Ch, Clive, E, Schulte-Nölke, H (2009), p. 3990-3994; Snyder, D V (1996), p. 424 ff.

92 Bar, von Ch, Clive, E, Schulte-Nölke, H (2009), p. 3699. 
The term unenforceability contained in Art. 7 (1) of the Portability Regulation, even though it presumably means an absolute nullity of respective contractual provisions, ${ }^{93}$ would probably cause problems of interpretation by national courts either due to the inconsistency with traditional concepts of invalidity known in the majority of the civil law jurisdictions, or due to inconsistency with the legal terms used in primary and secondary EU legislation for defining effects resulting from the breach of mandatory legal provisions.

It would be more consistent ${ }^{94}$ with the traditional concept of voidance and also with the terminology used in other EU regulations if Art. 7 (1) of the Portability Regulation contained the term "void" or "null and void". Such a solution would be more explicit and presumably lead to a more consistent application of the Portability Regulation by the courts in the EU Member States.

\subsection{PORTABILITY AS A SERIOUS BREACH OF THE CONTRACT}

If we address portability from the perspective of conformity with the contract, we see that the primary function here consists not in the nullity or the unenforceability of the contractual provision, but in the remedies (Art. 13 and 14 Digital Content Directive) that a consumer may request if the performance does not comply with the subjective or objective standards laid down by Art. 7 and 8 of the Digital Content Directive. The Digital Content Directive explicitly stipulates that the supplier shall be liable to the consumer for lack of conformity [Art. 14 Digital Content Directive].

The remedies referred to in Art. 14 of the Digital Content Directive correspond to the content and structure of consumer claims with rights

93 This may be deduced from the rationale of Recital 25 and Art. 7 (1) of the Portability Regulation. In the impact assessment [SWD (2015) 270 final, p. 45] it is declared that the restriction of the freedom to conduct a business (Art. 16 and 17 European Charter of Fundamental Rights) would be justified in light of the cross-border portability of online content services for European consumers. From this perspective, we can assume the obligation to enable cross-border portability [Art. 3 (1) Portability Regulation] and the parallel declaration that any contractual provisions which breach this obligation is unenforceable [Art. 7 (1) Portability Regulation], represent a breach of the mandatory legal rules. For this reason the violation of Art. 3 (1) of the Portability Regulation would constitute the absolute nullity (voidance) of any contractual provision which would not comply with these legal requirements. However, Engles and Nordemann conclude that the term unenforceability does not affect the validity of the provisions which contravene with Art. 3 (1) Portability Regulation and only makes them legally unenforceable. Engles, S; Nordemann, J B (2018), p. 195.

94 Inconsistency with the standard contract law terminology could have been precluded if the European Commission had used theoretical contributions which were formulated by European private-law projects. The differences between different concepts of nullity and unenforceability are clearly explained by the Draft Common Frame of Reference formulated by the Study Group on a European Civil Code and Acquis Group. See Fn. No. 91. 
conferred by Art. 3 (2) of the Consumer Sales and Guarantees Directive, but they are specially modified to the digital content. Thus, a hierarchy of remedies $^{95}$ is guaranteed at two levels. The basic remedy is that the consumer is entitled to have the digital content brought into conformity with the contract free of charge [Art. 12 (1) (3) Digital Content Directive]. At the second level, the consumer is entitled to terminate the contract, request a price reduction, ${ }^{96}$ or claim damages.

Criticisms of the hierarchy of remedies emerge when we compare the Digital Content Directive with the Consumer Sales and Guarantees Directive; it becomes evident that terminating a contract for the supply of digital content is effectively less harmful than terminating a contract for physical goods. ${ }^{97}$ In this respect it is argued that a consumer's option to immediately terminate a contract upon the breach of the conformity would enhance his or her negotiating position. ${ }^{98}$

Such criticism makes sense especially when we pay attention to portability issues. On the one hand, we can argue that if a supplier uses geo-blocking practices and the digital content is not available in another EU Member State, it is logical to remedy the situation by ensuring cross-border portability, since Art. 3 (1) of the Portability Regulation requires that the provider of an online content service will enable a consumer to access the online content service. On the other hand, we may ask why the consumer should be required to notify the provider in order to restore their access. However, it is possible that a provider might not be able to remove the geo-blocking mechanisms within a reasonable time frame [Art. 14 (3) Digital Content Directive]. Moreover, the supplier of the digital content might not be willing to bring the digital content into conformity with the contract because it is clear from the circumstances [Art. 12 (3) (e) Digital Content Directive] that geo-blocking is a commonly used practice.

We believe that in the sphere of the portability of the digital content a consumer should not first be forced to request that the provider enable cross-border portability, and only as a secondary claim be entitled to choose

${ }_{95}$ Zoll, F (2016), p. 253.

96 The Digital Content Directive refers only to the reduction of a monetary price since the reduction of personal data would hardly be possible [Art. 14 (4) Digital Content Directive]. Spindler, G (2016). Verträge über digitale Inhalte - Haftung, Gewährleistung und Portabilität Vorschlag der EU-Kommission zu einer Richtlinie über Verträge zur Bereitstellung digitaler Inhalte, p. 221.

97 Zoll, F (2016), p. 253.

98 Mak, C (2016), p. 24. 
between terminating the contract and reducing the price. The Digital Content Directive contains a rule that in specific cases in which non-conformity with the contract is of a serious nature [Art. 14 (4) (d) Digital Content Directive] the consumer should be entitled to pursue a price reduction or termination of the contract as a first course remedy.

A similar remedy was anticipated by the CESL when Art. 87 CESL regulated that the non-performance of an obligation by one party is fundamental if "(a) it substantially deprives the other party of what that party was entitled to expect under the contract, unless at the time of conclusion of the contract the nonperforming party did not foresee and could not be expected to have foreseen that result; or (b) it is of such a nature as to make it clear that the non-performing party's future performance cannot be relied on". In such a case, Art. 114 (1) of the CESL enabled the buyer to terminate the contract if the seller's non-performance under the contract was fundamental under the terms of Article 87 of the CESL. Furthermore, Art. 114 (2) of the CESL provided that in a "contract for the supply of digital content between a trader and a consumer, where there is a non-performance because the goods do not conform to the contract, the consumer may terminate the contract unless the lack of conformity is insignificant".

We can conclude that the portability requirements represent an important legal duty imposed on the provider of the digital content and the consumer should be automatically entitled to terminate the contract if the provider does not allow him or her access to digital content in the country of his or her temporary residence.

\subsection{PORTABILITY AND QUALITY}

Although the Portability Regulation allows a consumer access to online content services in a Member State of his temporarily presence [Art. 3 (1)], which should lead to the restoration of cross-border accessibility of digital content, the Portability Regulation reduces the quality requirements applied to such services available abroad [Recital 22, Art. 3 (3) Portability Regulation]. Although the provider is required to inform the consumer of the quality of the services accessible in other Member States [Art. 3 (4) Portability Regulation], the EU has chosen not to set legal requirements with regard to the quality of the service delivered in the other EU Member States [Art. 3 (3) Portability Regulation]. Thus, service providers would not be obliged to adapt the technical infrastructure necessary to ensure the same 
quality of their online services available in foreign countries. ${ }^{99}$ The Portability Regulation Impact Assessment explains that "if service providers see a need to adapt the technical infrastructure, it might lead to more substantial costs, e.g. the cost of upgrading the Internet connection of the origin server [...] Such costs would be substantial if providers of AV content services decide to invest in CDN in order to ensure quality of their service also when accessed in other $M S^{\prime \prime}{ }^{100}$

From a consumer law perspective, such an approach is very surprising since the Digital Content Directive, when defining the objective requirements of conformity with the contract, relies on the "standards, open technical specifications, good practices and codes of conduct" [Recital 50; Art. 8 (1) (a) Digital Content Directive].

If the quality of cross-border online content services is not covered by the Portability Regulation and especially if such quality is reflected only if the provider expressly acknowledges ${ }^{101}$ in the licence or service contract that he or she will enable the same quality of accessibility of the digital content in another Member State [Art. 3 (3) Portability Regulation], then the contractual position of the consumer is obviously very weak. Actually, such a permissible reduction of quality may lead to circumventing the prohibition of geo-blocking practices. From the perspective of conformity with the contract, we see that even though there might be existing "technical standards" which are applied internationally (or in certain fields of online content services), ${ }^{102}$ it would not be possible to apply them since the Portability Regulation, as a particular piece of EU legislation [Recital 36; Art. 3 (7) Digital Content Directive], excludes provider liability for the quality of the online content services in cross-border situations.

These risks have probably been precluded by Art. 3 (1) Portability Regulation which aimed to enhance the quality of online services provided abroad. The provider of an online content service provided against payment of money shall enable the accessibility to digital content in the same manner as in the Member State of residence "including by providing access to the same content, on the same range and number of devices, for the same number of users

\footnotetext{
99 SWD (2015) 270 final, p. 32, 59; Engles, S; Nordemann, J B (2018), p. 187.

100 SWD (2015) 270 final, p. 42.

101 COM (2015) 627 final, p. 8.

102 Loos, M B M et al. (2011), p. 47, 48.
} 
and with the same range of functionalities". Furthermore, the provider shall neither "take any action to reduce the quality of delivery of the online content service" [Art. 3 (3) Portability Regulation] nor "impose any additional charges on the subscriber for the access to and the use of the online content service" [Art. 3 (2) Portability Regulation].

\section{CONCLUSIONS}

When we analyse the relation between the Digital Content Directive and the Portability Regulation we see that both legislative acts address the issue of access to digital content from different perspectives. The Portability Regulation focuses on the cross-border portability of digital content in other EU Member States [Art. 3 (1) Portability Regulation), while the Digital Content Directive specifies the consumer rights related to the distribution of digital content and subsumes the accessibility of the digital content under the notion of the "conformity of the digital content with the contract" [Art. 8 (1) Digital Content Directive).

We have argued that even though both pieces of EU legislation use different legal terminology and, in some aspects, have different scopes of application, they can be complementary in the question of cross-border portability of digital content provided to consumers for monetary counter performance. This means that the Portability Regulation will be applied in respect to the cross-border accessibility of digital content, but other issues, such as remedies concerned with the non-availability of the digital content, will fall under the scope of the Digital Content Directive, respectively under national regulations, which will be issued to transpose the directive into national law.

Furthermore, we have deduced that the Portability Regulation contains the mandatory legal provisions which limit the contractual freedom of the copyright holders and service providers. The dissemination model of digital assets must respect the basic principles of the EU single market such as free movement of goods and services [Art. 26 (2), Art. 56 TFEU] and the protection of the consumer [Art. 12, Art. 114 (3), Art. 169 TFEU]. Such legal requirements could not be solved by the adoption of the EU Copyright Regulation (adopted under Art. 118 TFEU, which would create a unitary EU copyright protection). Therefore, the EU legislator have correctly focused on removing territorial barriers in the sphere of contract law. Under the regime of unitary rights, we may still find examples in which licences 
are granted not for the entire territorial scope of protection, but for several states only. The cross-border accessibility of digital content is thus not primarily a question of the territoriality of the copyright but a question of copyright holders' and service providers' licencing policies.

\section{LIST OF REFERENCES}

[1] Arnerstål, S (2015). Licensing digital content in a sale of goods context. GRUR Int., Volume 64, Issue 9

[2] Bach, I (2019) Neue Richtlinien zum Verbrauchsgüterkauf und zu Verbraucherverträgen über digitale Inhalte. Neue Juristische Wochenschrift. Volume 72, Issue 24 .

[3] Bar, von Ch, Clive, E, Schulte-Nölke, H (2009) Principles, Definitions and Model Rules of European Private Law Draft Common Frame of Reference (DCFR). [online] Available from: https://www.ccbe.eu/fileadmin/speciality_distribution/public/documents/EURO PEAN_PRIVATE_LAW/EN_EPL_20100107_Principles_definitions_and_model_rules_ of_European_private_law_Draft_Common_Frame_of_Reference_DCFR_pdf [Accessed 28 May 2021].

[4] Bar, von Ch, Swann, S (2010) Principles of European Law. Study Group on a European Civil Code. Unjustified Enrichment. Munich: Sellier.

[5] Beale, H (2013) The CESL Proposal: An Overview. Juridica International. Volume 20, Issue 1.

[6] Beale, H (2016) Scope of application and general approach of the new rules for contracts in the digital environment. Workshop of JURI-Committee of the European Parliament. [online] Available from: http://www.epgencms.europarl.europa.eu/cmsdata/upload/4a1651c40db0-4142-9580-89b47010ae9f/pe_536.493_print.pdf [Accessed 28 May 2021].

[7] Beale, H (2016) The future of European contract law in the light of the European C ommission's proposals for Directives on digital content and online sales. IDP: Revista de Internet, Derecho y Politica. Issue 23.

[8] Craig, P, de Burca G. (eds.) (1999). The Evolution of EU Law, Oxford: Oxford University Press.

[9] Carvalho, J M (2019) Sale of Goods and Supply of Digital Content and Digital Services - Overview of Directives 2019/770 and 2019/771, Journal of European Consumer and Market Law, Volume 8, Issue 5. 
[10] Clive, E (2015). Proposal for a Common European Sales Law withdrawn. at: https://www.unisob.na.it/universita/facolta/giurisprudenza/age/proposal_cesl_withdra wn.pdf

[11] European Commission (2015) Communication from the Commission to the European Parliament, the Council, the European Economic and Social Committee and the Committee of the Regions. A Digital Single Market Strategy for Europe from 6.5.2016, COM (2015) 192 final. [online] Available from: https:/eur-lex.europa.eu/legalcontent/EN/TXT/uri=CELEX\%3A52015DC0192 [Accessed 28 May 2021].

[12] European Commission (2015) Communication from the Commission to the European Parliament, the Council, the European Economic and Social Committee and the Committee of the Regions Towards a modern, more European copyright framework from 9.12.2015, COM (2015) 626 final. [online] Available from: https://ec.europa.eu/transparency/regdoc/rep/1/2015/EN/1-2015-626-EN-F1-1.PDF [Accessed 28 May 2021].

[13] European Commission (2014) Communication from the Commission to the European Parliament, the Council, the European Economic and Social Committee and the Committee of the Regions. Commission Work Programme 2015. A New Start, from 16. 12. 2014, COM (2014) 910 final. [online] Available from: https://eur-lex.europa.eu/legal-content/EN/ALL/? uri=COM:2014:910:FIN [Accessed 28 May 2021].

[14] European Commission (2015) Communication from the Commission to the European Parliament, the Council, the European Economic and Social Committee. Digital contracts for Europe - Unleashing the potential of e-commerce from 9.12.2015, COM/2015/0633 final. [online] Available from: https://eur-lex.europa.eu/legal-content/en/TXT/?uri=CELEX \%3A52015DC0633 [Accessed 28 May 2021].

[15] European Commission (2011) Communication from the Commission to the European Parliament, the Council, the European Economic and Social Committee and the Committee of the Regions: A Single Market for Intellectual Property Rights/Boosting creativity and innovation to provide economic growth, high quality jobs and first class products and services in Europe from 24.5.2011, $\operatorname{COM}(2011) 287$ final. [online] Available from: https://eur-lex.europa.eu/legal-content/en/TXT/?uri=CELEX\%3A52011DC0287 [Accessed 28 May 2021].

[16] European Commission (2016) Commission Staff Working Document: Evaluation of the Council Directive 93/83/EEC on the coordination of certain rules concerning copyright and rights related to copyright applicable to satellite broadcasting and cable retransmission from 
14.9.2016, SWD (2016) 308 final. [online] Available from: http:/edz.bib.unimannheim.de/edz/pdf/swd/2016/swd-2016-0308-en.pdf [Accessed 28 May 2021].

[17] De Franceschi, A (2016) European Contract Law and the Digital Single Market: The Implications of Digital Revolution. Mortsel: Intersentia.

[18] Engles, S; Nordemann, J B (2018) The Portability Regulation (Regulation (EU) 2017/1128): A Commentary on the Scope and Application. Journal of Intellectual Property, Information Technology and Electronic Commerce, Volume 9, Issue 2.

[19] Helberger, N et al. (2013) Digital Content Contracts for Consumers. Journal of Consumer Policy. Volume 36, Issue 1.

[20] Helberger, N, Hugenholtz, P B (2007), No place like home for making a copy: private copying in European copyright law and consumer law, Berkeley Technology Law Journal, Volume 22, Issue 3.

[21] Hoffman, J (2016) Crossing Borders in the Digital Market: A Proposal to End Copyright Territoriality and Geo-Blocking in the European Union. George Washington International Law Review, Volume 49, Issue 3.

[22] European Commission (2015) Impact Assessment: Proposal for a Regulation of the European Parliament and of the Council to ensure the cross-border portability of online content services in the internal market from 9.12.2015. SWD (2015) 270 final. [online] Available from: https://ec.europa.eu/transparency/regdoc/rep/1/2015/EN/1-2015-627-EN-F1-1.PDF [Accessed 28 May 2021].

[23] European Commission (2015) Impact Assessment: Proposals for Directives of the European Parliament and of the Council (1) on certain aspects concerning contracts for the supply of digital content and (2) on certain aspects concerning contracts for the online and other distance sales of goods from 17.12.2015. SWD(2015) 274 final/2. [online] Available from: https://eurlex.europa.eu/LexUriServ/LexUriServ.do?uri=SWD:2015:0274:FIN:EN:PDF [Accessed 28 May 2021].

[24] Koukal, P (2018) Consumer Protection and the Portability Regulation. In Staníčková, $\mathrm{M}$ (eds.) Proceedings of the 4th International Conference on European Integration. Ostrava: VŠB - Technical University of Ostrava.

[25] Licences for Europe - Structured Stakeholder Dialogue 2013, WG 1 Audio-visual Subgroup, Joint Statement on Cross-border Portability of lawfully-acquired Audiovisual Content. [online] Available from: https:/ec.europa.eu/licences-for-europedialogue/sites/licences-for-europe-dialogue/files/1-AV-portability.pdf [Accessed 28 May 2021]. 
[26] Loewenheim, U (2010) Handbuch des Urheberrechts. 2nd ed. Verlag C.H.Beck, München.

[27] Loos, M B M et al. (2011). Analysis of the applicable legal frameworks and suggestions for the contours of a model system of consumer protection in relation to digital content contracts. [online] Available from: https://op.europa.eu/en/publicationdetail/-/publication/4fee0cc7-5f4d-46c5-897b-48844f07f027 [Accessed 28 May 2021].

[28] Mak, C (2016) The new proposal for harmonised rules on certain aspects concerning contracts for the supply of digital. [online] Available from:: http://www.europarl.europa.eu/supporting-analyses [Accessed 28 May 2021].

[29] Mazziotti, G (2016) Is Geo-blocking a Real Cause for Concern in Europe?'(2016). EIPR. Volume 38, Issue 6.

[30] Micklitz, H W (1999) Principles of Social Justice in European Private Law. Yearbook of European Law. Volume 19, Issue 1.

[31] Netflix Media Center Terms and Conditions. [online] Available from: https://media.netflix.com/en/terms-and- conditions [Accessed 28 May 2021].

[32] Cherednychenko, O (2007) Fundamental Rights, Contract Law and the Protection of the Weaker Party: A Comparative Analysis of the Constitutionalisation of Contract Law. Sellier, München.

[33] Oprysk, L, Sein, K (2020) Limitations in End-User Licensing Agreements: Is There a Lack of Conformity Under the New Digital Content Directive? IIC - International Review of Intellectual Property and Competition Law, Volume 51, Issue 5.

[34] Pongelli, G (2013) The Proposal for a Regulation on a Common European Sales Law (CESL) and its Gradual Evolution. Comparative Law Review. Volume 4, Issue 1.

[35] European Commission (2015) Proposal for a Directive of the European Parliament and of the Council on certain aspects concerning contracts for the online and other distance sales of goods from 9.12.2015, $\operatorname{COM}(2015) 635$ final. [online] Available from: https:/ec.europa.eu/transparency/regdoc/rep/1/2015/EN/1-2015-635-EN-F1-1.PDF [Accessed 28 May 2021].

[36] European Commission (2016) Proposal for a Regulation of the European Parliament and of the Council on addressing geo-blocking and other forms of discrimination based on customers' nationality, place of residence or place of establishment within the internal market and amending Regulation (EC) No 2006/2004 and Directive 2009/22/EC from 25.5.2016, COM (2016) 289. [online] Available from: https://ec.europa.eu/transparency/regdoc/rep/1/2016/EN/1-2016289-EN-F1-1.PDF [Accessed 28 May 2021]. 
[37] European Commission (2015) Proposal for a Regulation of the European Parliament and of the Council on ensuring the cross-border portability of online content services in the internal market from 9.12.2015, COM (2015) 627 final. [online] Available from: https://ec.europa.eu/transparency/regdoc/rep/1/2015/EN/1-2015-627-EN-F1-1.PDF [Accessed 28 May 2021].

[38] European Commission (2011) Proposal for a Regulation of the European Parliament and of the Council on a Common European Sales Law, COM (2011) 635 final. [online] Available from: https://eur-lex.europa.eu/legal-content/EN/ALL/?uri=CELEX:52011PC0635 [Accessed 28 May 2021].

[39] Rafel, R M (2016) The Directive Proposals on Online Sales and Supply of Digital Content (Part I): will the new rules attain their objective of reducing legal complexity. IDP: Revista de Internet, Derecho y Politica. Issue 23.

[40] Ramalho, A (2014) Conceptualising the European Union's Competence in Copyright - What Can the EU Do? International Review of Intellectual Property and Competition Law. Volume 45, Issue 2.

[41] Schulze, R, Schulte-Nölke H (eds.) (2011) European Private Law - Current Status and Perspectives. München: Sellier.

[42] Schulze, R (2012) Common European Sales Law (CESL) - Commentary. BadenBaden, München, Oxford: C.H. Beck, Hart, Nomos.

[43] Scottish Law Commission (2011) An Optional Common European Sales Law: Advantages and Problems Advice to the UK Government, The Law Commission and The Scottish Law Commission. [online] Available from: http://www.lawcom.gov.uk/app/uploads/2015/03/Common_European_Sales_Law_ Summary.pdf [Accessed 28 May 2021].

[44] Snyder, D V (1996) The Case of Natural Obligations. Lousiana Law Review. Volume 56, Issue 2.

[45] Spindler, G (2016). Die Modernisierung des europäischen Urheberrechts Der Vorschlag zur Portabilitäts-VO und die Planungen der EU-Kommission. Computer und Recht, Volume 32, Issue 2.

[46] Spindler, G (2016) Digitale Wirtschaft -- analoges Recht: Braucht das BGB ein Update? Juristenzeitung. Volume 71, Issue 17.

[47] Spindler, G (2016) Verträge über digitale Inhalte - Anwendungsbereich und Ansätze Vorschlag der EU-Kommission zu einer Richtlinie über Verträge zur Bereitstellung digitaler Inhalte. Multimedia und Recht, Volume 19, Issues 3, 4. 
[48] Spindler, G (2016) Verträge über digitale Inhalte - Haftung, Gewährleistung und Portabilität Vorschlag der EU-Kommission $\mathrm{zu}$ einer Richtlinie über Verträge zur Bereitstellung digitaler Inhalte, Multimedia und Recht, Volume 20, Issue 4.

[49] Spindler, G, Sein, K (2019) Die endgültige Richtlinie über Verträge über digitale Inhalte und Dienstleistungen. MMR - Zeitschrift für IT-Recht und Recht der Digitalisierung. Volume 22, Issue 7.

[50] Staudenmayer, D (2016) Verträge über digitalen Inhalt Der Richtlinienvorschlag der Europäischen Kommission. Neue Juristische Wochenschrift. Volume 69, Issue 37.

[51] Synodinou, T E (2020) Geoblocking in EU Copyright Law: Challenges and Perspectives. GRUR International. Volume 69, Issue 2.

[52] Synodinou, T E (2020). EU Internet Law: Regulation and Enforcement. Cham: Springer Nature Switzerland AG.

[53] Thomas, J. et al. (2015) Statement of the European Law Institute On the European Commission's proposed Directive on the Supply of Digital Content to Consumers COM (2015) 634 final. [online] Available from: http://www.europeanlawinstitute.eu/home/news-contd/article/the-eli-publishes-itsstatement-on-the-european-commissions-proposed-directive-on-the-supply-of-dig/? tx_ttnews\%5BbackPick\%5D=180991\&cHash=c0009025cff265addbd4819c8110e410 [Accessed 28 May 2021].

[54] Trimble M (2012) The Future of Cybertravel: Legal Implications of the Evasion of Geolocation. Fordham Intellectual Property Media \& Entertainment Law Journal. Volume 22, Issue 3.

[55] Trimble, M (2016) The role of geoblocking in the Internet legal landscape. IDP: Revista de Internet, Derecho y Politica. Issue 23.

[56] Twigg-Flesner, Ch (2013) The Europeanisation of Contract Law. Current controversies in law. 2nd ed. London (UK), New York (USA): Routledge.

[57] Zoll, F (2016) The Remedies in the Proposals of the Only Sales Directive and the Directive on the Supply of Digital Content. Journal of European Consumer and Market Law, Volume 5, Issue 6. 